Original Paper http://ajol.info/index.php/ijbcs http://indexmedicus.afro.who.int

\title{
Growth, mineral uptake, chlorophyll content, biochemical constituents and non-enzymatic antioxidant compounds of white pepper (Piper nigrum $\mathbf{L}$.) grown under saline conditions
}

\author{
Alphonse Ervé NOUCK ${ }^{1 *}$, Mathias Julien HAND ${ }^{2}$, Elvis Ngwa NUMFOR ${ }^{1}$, \\ Serge Sondi EKWEL ${ }^{3}$, Cécile Mbondjo NDOUMA ${ }^{3}$, Erica Wiraghan SHANG ${ }^{1}$ and \\ Victor Désiré TAFFOUO ${ }^{3}$
}

\author{
${ }^{1}$ Department of Biological Sciences, Faculty of Sciences, the University of Bamenda, P.O. Box 39 Bambili- \\ Cameroon. \\ ${ }^{2}$ Department of Biological Sciences, Faculty of Sciences, the University of Maroua, P.O.Box 46 Maroua- \\ Cameroun. \\ ${ }^{3}$ Department of Botany, Faculty of Science, the University of Douala, P.O. Box 24157, Douala-Cameroon. \\ *Corresponding author; E-mail: alphonseervenouck@yahoo.fr; Phone: 00237677228724
}
Received: 01-03-2021
Accepted: 11-08-2021
Published: 31-09-2021

\begin{abstract}
Salinity stress is the main abiotic constraints limiting crop yield worldwide. We investigated the effect of salt stress on growth, dry weight partitioning, chlorophyll content, mineral uptake, biochemical constituents and non-enzymatic antioxidant compounds of white pepper (Piper nigrum L.). White pepper seeds were planted in polythene bags previously filled with sand and supplied with a nutrient solution in a greenhouse during six weeks as a completely randomized design. Plants were subjected to four different concentrations of $\mathrm{NaCl}(0,50,100$ and $200 \mathrm{mM})$. Supplies of intake doses of $\mathrm{NaCl}$ in the culture medium significantly decreased the dry biomass, stem height, leaf area and chlorophyll contents respectively from $100 \mathrm{mM} \mathrm{NaCl}$. Mineral elements $(\mathrm{K}, \mathrm{Ca}$ and $\mathrm{Mg}$ ) significantly $(\mathrm{P}<0.001)$ decreased in plant organs. The different biochemical constituents (proline, total soluble carbohydrates, soluble proteins and total free amino acids), total phenolic and flavonoids contents significantly $(\mathrm{P}<0.001)$ increased from $50 \mathrm{mM} \mathrm{NaCl}$. The accumulation of biochemical constituents in the leaves increased the osmotic potential of white pepper and could be considered as biochemical indicators of early selection and osmotic adjustment ability for salt tolerant plants. The planting of white pepper in salt affected soils could be encouraged for better development.
\end{abstract}

(C) 2021 International Formulae Group. All rights reserved.

Keywords: Growth parameters, biochemical constituents, salinity, mineral uptake, Piper nigrum.

\section{INTRODUCTION}

Salinity is one of the major factors that affect plant growth and metabolism, consequently causing damage and loss of crop or yield in Littoral, semi-arid and arid zones
(Taïbi et al., 2016; Hand et al., 2017; Kpinkoun et al., 2019; Kinsou et al., 2021). It is caused by saline parent bed rocks, mineral degradation, invasion of sea water in coastal regions and the over use of saline water 
irrigation (Ndouma et al., 2020). More than 60 million ha of irrigated land has been damaged by salt (Nouck et al., 2016). Elevated salt concentrations around plant roots induce an imbalance in water potential, cellular dehydration, inhibition of intracellular enzyme activities, cell division and expansion reduction in growth and productivity (Diallo et al., 2013; Kosovà et al., 2013).

Many authors have done works on mineral uptake by plants under salt-stress conditions (Meguekam et al., 2014; Nouck et al., 2016; Hand et al., 2017; Ndouma et al., 2020). They showed that the inhibition of potassium, calcium and magnesium by sodium is a result of $\mathrm{K}^{+} / \mathrm{N}^{+}$antagonism. In addition, they also linked the decrease of photosynthetic activity under salinity stress to the closure of stomata due to low intercellular $\mathrm{CO}_{2}$ levels.

In response to salinity, plants produce biochemical constituents (proline (PRO), total free amino acids (FAA), soluble proteins (SP), and total soluble carbohydrates $(\mathrm{CH})$ ) and non-enzymatic antioxidant compounds (Total phenolic (TP) and flavonoid compounds (FLA)). Salt tolerance is determined by osmotic adjustment maintenance of ion homeostasis, the control of ion and water flux, the specific protein and free radical enzymes involved in the protection of protoplast functions (Hand et al., 2017; Ndouma et al., 2020). Numerous studies have shown that PRO acts as a mediator in osmotic adjustment stabilizing the effect of salt accumulated in the vacuole (Khalil et al., 2016). SP needed in osmotic adjustment during salt stress are stored as nitrogen and re-used when the stress is removed (Nouck et al., 2016; Hand et al., 2017). The production and storage of FAA and $\mathrm{CH}$ during stress conditions is adaptive response (Ndouma et al., 2020). TP participates in the regulation of growth and development and acts as defense mechanism against biotic and abiotic stress (Chenier et al., 2013; Taïbi et al., 2016). FLAs are the main subgroup of polyphenols with a wide array of biological functions including lipid peroxidation inhibition (Di Ferdinando et al., 2012). Accumulation of TP and FLA during stress could be cellular adaptive mechanisms for scavenging oxygen free radicals (Meguekam et al. 2014).

White pepper (Piper nigrum L.) is considered as an important cash crop in Cameroon. It can be consumed as spice, used for seasoning food during preparation (Meghwal and Ghoswani, 2012). It is thought to improve human health as it contains piperine, which is antipyretic, analgesic, performs a protective role on key liver enzymes and has antimicrobial activity. Investigating crop plant species with genetic potential for salinity tolerance are better approaches for developing salt tolerant cash crop cultivars (Munns and Tester, 2008). Therefore, the aim of this work was to study the effects of $\mathrm{NaCl}$ on growth, mineral uptake, chlorophyll contents, biochemical constituents and non-enzymatic antioxidant compounds of white pepper, providing additional information on the mechanism of salt tolerance and so improve salt tolerance in plants for research and breeding programs.

\section{MATERIALS AND METHODS}

\section{Study area}

The study was carried out in a greenhouse of Faculty of Science, The University of Bamenda located in BambiliCameroon. Bambili ( $5^{\circ} 60^{\prime}$ 33" North and longitude $10^{\circ} 15^{\prime} 21^{\prime \prime}$ East, Elevation $1444 \mathrm{~m}$ ) is found in Mezam division of the North West region of Cameroon. The work was carried out from October 2018 to July 2019, Average rain fall and temperatures are $854 \mathrm{~mm} /$ year and $30{ }^{\circ} \mathrm{C}$ and relative humidity is nearest to $84 \%$. Prevailing winds carry the tropical monsoon.

\section{Plant material}

White pepper (Piper nigrum L.) is an economically important plant which is used as condiments and has many medicinal and pharmacological properties (Meghwal and 
Ghoswani, 2012). It is currently cultivated in the tropics worldwide (Scot and Eger, 2011). The samples used were provided by the Institute of Agronomic Research and Development (IRAD) breeding program of Cameroon.

\section{Plant growth conditions and salt treatments Seeds pretreatment}

After carrying out a viability test, seeds were pretreated following the methodology of Maydell (1986). Seeds were pre-warmed in cotton bag by placing the bag in a warm water bath. The temperature of the water was first increased and a thermometer was used to monitor the temperature. When the water reached $50^{\circ} \mathrm{C}$, the cotton bag containing seeds was placed in the warm water and kept suspended in the container of water while the water was stirred regularly to ensure that all seeds were evenly heated. After 30 minutes, the seeds were removed and immediately put in cold water to quickly stop the heating process and then put in 3\% sodium hypochlorite for 15 minutes. It was washed five times with demineralized water and sown in $4 \mathrm{~L}$ polythene bags filled with sterilized sand. The plants were arranged in a complete randomized block design one plant per bag. Each treatment had 5 replications. They were enriched on daily basis with a modified nutrient solution. (in $\mathrm{g} / \mathrm{L}$ ) made of $150 \mathrm{~g}$ $\mathrm{Ca}(\mathrm{NO} 3)_{2}, 70 \mathrm{~g} \mathrm{KNO}_{3}, 15 \mathrm{~g} \mathrm{Fe}-\mathrm{EDTA}, 0.14 \mathrm{~g}$ $\mathrm{KH}_{2} \mathrm{PO}_{4}, 1.60 \mathrm{~g} \mathrm{~K}_{2} \mathrm{SO}_{4}, 11 \mathrm{~g} \mathrm{MgSO}_{4}, 2.5 \mathrm{~g}$ $\mathrm{CaSO}_{4}, 1.18 \mathrm{~g} \mathrm{MnSO}_{4}, 0.16 \mathrm{~g} \mathrm{ZnSO}_{4}, 3.10 \mathrm{~g}$ $\mathrm{H}_{3} \mathrm{BO}_{4}, 0.17 \mathrm{~g} \mathrm{CuSO}_{4}$ and $0.08 \mathrm{~g} \mathrm{MOO}_{3}$ (Hoagland and Arnon, 1950). The $\mathrm{pH}$ of the nutrient solution was adjusted to 7.0 by adding $\mathrm{HNO}_{3} 0.1 \mathrm{mM}$. White pepper plants were subjected to four different salt concentrations $(0.50 .100$ and $200 \mathrm{mM} \mathrm{NaCl})$, with $0 \mathrm{mM} \mathrm{NaCl}$ as a control for duration of six weeks, in a culture medium so as to determine physiological and biochemical responses of cultivars to salt stress. The average day and night temperatures in the greenhouse were between 26 and $20{ }^{\circ} \mathrm{C}$ respectively during the growth period with an average relative air humidity of $69.5 \%$. Parameters were evaluated under greenhouse condition: growth parameters considered were (dry weight of roots and shoots, Chlorophyll content, biochemical constituents (soluble proteins, carbohydrates, total free amino acids and proline content), mineral uptake ( $\mathrm{Na}, \mathrm{K}$, $\mathrm{Ca}$ and $\mathrm{Mg}$ contents of roots and shoots) and non-enzymatic antioxidants (total phenolic and flavonoids content).

\section{Growth parameters}

The leaf area, noose diameter, the number of leaves, stem height, and dry weight were recorded for six weeks, after which, the plants were harvested. The stem height and noose diameter were determined by measuring with a ruler and vernier caliper respectively, and the number of leaves were determined by counting (Ndouma et al., 2020). Roots and shoots were dried separately at $60{ }^{\circ} \mathrm{C}$ for 72 Hours and their dry biomasses were determined. Leaf area was calculated using the Taillièz and Ballo (1992) formula, surface area $\left(\mathrm{cm}^{2}\right)=1 / 3$ (Length $\times$ Width).

\section{Mineral distribution}

For the determination of sodium $\left(\mathrm{Na}^{+}\right)$, potassium $\left(\mathrm{K}^{+}\right)$, calcium $\left(\mathrm{Ca}^{2+}\right)$ and magnesium $\left(\mathrm{Mg}^{2+}\right)$ concentrations in the shoots and roots, $2 \mathrm{~g}$ of dried organs (shoots and roots) were separately reduced to ashes by heating at $550{ }^{\circ} \mathrm{C}$ for 4 hours and thoroughly mixed with $250 \mathrm{~mL}$ of deionized water. The filtrate was analysed with an atomic absorption spectrophotometer (Rayleigh WFX-100) (Pauwels et al., 1992) method.

\section{Chlorophyll content}

The chlorophyll content was determined using the Arnon (1949) method. $0.80 \mathrm{~g}$ sample of fresh leaves were crushed and their contents extracted with $80 \%$ of alkaline acetone $(\mathrm{v} / \mathrm{v})$. The filtrate was analyzed using a spectrophotometer (Pharmaspec model UV-1700) at 645 and 663 nm wavelengths. 


\section{Biochemical constituents \\ Total free amino acids content}

Total free amino acids content (FAA)

was determined by using the ninhydrin method (Yemm and Cocking, 1955). Fresh leaves $(1 \mathrm{~g})$ were ground in $5 \mathrm{~mL}$ of ethanol $80 \%$, amino acids were then extracted using reflux technique in boiling ethanol for $30 \mathrm{~min}$. After decanting, the supernatant was filtered using Whatman $\mathrm{N}^{\circ} 1$ filter paper. The filtrate was collected and the residue used to repeat the extraction. The two filtrates were mixed and the raw extract of amino acid content was measured using ninhydrin method. The absorbance of purplish-blue complex was read at $570 \mathrm{~nm}$ wavelength. The standard curve was established using $0.1 \mathrm{mg} / \mathrm{mL}$ of glycine.

\section{Proline content}

Proline content (PRO) was estimated using Bates et al. (1973) method. $0.5 \mathrm{~g}$ of fresh leaves were weighed and put inside a flask. $10 \mathrm{~mL}$ of $3 \%$ aqueous sulphosalicylic acid was poured in the same flask. The mixture was homogenized, and then filtered with a Whatman $\mathrm{N}^{\circ} 1$ filter paper. $2 \mathrm{~mL}$ of filtered solution was poured into a test tube, and then $2 \mathrm{~mL}$ of glacial acetic acid and ninhydrin acid were respectively added into the same tube. The test tube was heated in a warm bath for $1 \mathrm{~h}$. The reaction was stopped by placing the test tube in an ice bath. $4 \mathrm{~mL}$ of toluene was added to the test tube and stirred. The toluene layer was separated at room temperature, the mixture purple color and the absorbance of the purple mixture was read at $520 \mathrm{~nm}$ by spectrophotometer UV (Pharmaspec model UV-1700). At $520 \mathrm{~nm}$, the absorbance was recorded and the concentration of PRO was determined using a standard curve as $\mu \mathrm{g} / \mathrm{g}$ FW.

\section{Soluble carbohydrate content}

Soluble carbohydrate $(\mathrm{CH})$ content was obtained using phenol-sulphuric acid (Dubois et al., 1956). The fresh leaves $(1 \mathrm{~g})$ were grounded in $5 \mathrm{~mL}$ of $80 \%$ ethanol and filtered with the Whatman No 1 filter paper. The collected extracts were diluted by deionized water to $50 \mathrm{~mL} .1 \mathrm{~mL}$ of each sample was poured in test tube, then $1 \mathrm{~mL}$ of phenol solution and $5 \mathrm{~mL}$ of sulphuric acid were added. The mixture was then swirled. The absorbance was read at $490 \mathrm{~nm}$ using a spectrophotometer (Pharmaspec UV-1700 model). The quantity of $\mathrm{CH}$ was deduced from the glucose standard curve.

\section{Soluble proteins content}

Soluble proteins content (PR) was evaluated using Bradford (1976) method. The standard protein used was the bovine serum albumin (BSA). $0.1 \mathrm{~g}$ of fresh leaves were ground and mixed with $4 \mathrm{~mL}$ of an already prepared sodium-phosphate buffer, $\mathrm{pH}$ 7.2. The mixture was then centrifuged at 13000 $\mathrm{rpm}$ for $4.5 \mathrm{~min}$ at $4{ }^{\circ} \mathrm{C}$. $1 \mathrm{~mL}$ of the supernatant was poured into a tube containing $5 \mathrm{~mL}$ of the Bradford reagent. The mixture was shaken and incubated in the dark for 15 min. The absorbance of the resulting blue complex was read at $595 \mathrm{~nm}$ with a spectrophotometer UV (PG instruments T60). The standard curve was obtained using BSA 1 $\mathrm{mg} / \mathrm{mL}$.

\section{Non enzymatic antioxidants Flavonoids content}

Flavonoids content (FLA) of crude extract was determined by the aluminum chloride colorimetric method (Chang et al., 2002). $50 \mu \mathrm{L}$ of crude extract $(1 \mathrm{mg} / \mathrm{mL}$ ethanol) was made up to $1 \mathrm{~mL}$ with methanol, mixed with $4 \mathrm{~mL}$ of distilled water and then $0.3 \mathrm{~mL}$ of $5 \% \mathrm{NaNO}_{2}$ solution; $0.3 \mathrm{~mL}$ of $10 \% \mathrm{AlCl}_{3}$ solution was added after 5 minutes of incubation, and the mixture was allowed to stand for 6 minutes. Then, $2 \mathrm{~mL}$ of $1 \mathrm{~mol} / \mathrm{L}$ $\mathrm{NaOH}$ solution were added, and the final volume of the mixture was brought to $10 \mathrm{~mL}$ with double-distilled water. The mixture was allowed to stand for $15 \mathrm{~min}$, and absorbance was recorded on spectrophotometer (Pharmaspec UV-1700 model) at $510 \mathrm{~nm}$ wavelength. FLA content was calculated from a grutin calibration curve, and the result was 
expressed as grutin equivalent per g dry weight.

\section{Total phenolic content}

Total phenolic content (TP) was determined using the folin-ciocalteu method (Marigo, 1973). $1 \mathrm{~g}$ of fresh leaves was ground at $4{ }^{\circ} \mathrm{C}$ for 20 minutes in $3 \mathrm{~mL}$ of 0.1 $\mathrm{NHCl}$, the homogenate was centrifuged at $6000 \mathrm{~g}$ during 40 minutes. The pellet resuspended in $3 \mathrm{~mL}$ of $0.1 \mathrm{NHCl}$ and centrifuges previously. The two supernatant are mixed and constitute the crude extract of soluble phenol. The reaction mixture containing $15 \mu \mathrm{L}$ of extract $100 \mu \mathrm{L}$ folinciocalteu reagents, $0.5 \mathrm{~mL}$ of $20 \% \mathrm{Na}_{2} \mathrm{CO}_{3}$ was incubated at $40{ }^{\circ} \mathrm{C}$ for 20 minutes and absorbance read at $720 \mathrm{~nm}$ wavelength with a spectrophotometer (Pharmaspec UV-1700 model). The TP (mg/g FW) content was determined through a standard curve established by using chlorogenic acid.

\section{Statistical analysis}

The experiment was performed using the complete randomized design. All data were presented in terms of mean $( \pm$ standard deviation), statistically analysed using Graph pad Prism version 5.01 and subjected to analysis of variance (ANOVA). Statistical differences between treatment means were established using the Fisher Least Significant Difference (LSD) at $\mathrm{P}<0.05$.

\section{RESULTS}

\section{Plant growth}

The growth parameters (stem height (SH), number of leaves (NL), noose diameter (ND), leaf area (LA) and dry weight of roots (RDW) and shoots (SDW)) were generally influence by intake doses of $\mathrm{NaCl}$ and decreased significantly in the culture medium during six weeks from 100 to $200 \mathrm{mM}$ of $\mathrm{NaCl}$ (Table 1). Stem height, roots and shoots dry weight significantly decreased $(\mathrm{P}<0.001)$ from 100 to $200 \mathrm{mM}$ of $\mathrm{NaCl}$, number of leaves and leaf area significantly decreased $(\mathrm{P}$ $<0.01$ ) from $100 \mathrm{mM}$ of $\mathrm{NaCl}$ while the noose diameter significantly decreased $(\mathrm{P}<$ 0.05 ) from the same concentration (Table 1).

\section{Mineral distribution}

The $\mathrm{Na}^{+}$significantly increased $(\mathrm{p}<$ 0.001 ) with increased doses of $\mathrm{NaCl}$ in plant partitioning from $50 \mathrm{mM} \mathrm{NaCl}$ (Table 2). The others mineral $\left(\mathrm{K}^{+}, \mathrm{Ca}^{2+}\right.$ and $\left.\mathrm{Mg}^{2+}\right)$ showed significant decrease $((\mathrm{p}<0.05),(\mathrm{p}<0.001)$ and $(\mathrm{p}<0.001)$ respectively from $100 \mathrm{mM}$ $\mathrm{NaCl})$ occurred with increased doses of $\mathrm{NaCl}$ for roots and significant decrease $(\mathrm{p}<0.001)$ from $50 \mathrm{mM} \mathrm{NaCl}$ in the shoots (Table 2).

\section{Chlorophyll contents}

The chlorophyll contents were generally affected by the increased doses of $\mathrm{NaCl}$ in the culture medium. The chlorophyll $\mathrm{a}, \mathrm{b}$ and $(\mathrm{a}+\mathrm{b})$ significantly sloped down $(\mathrm{P}<$ $0.05)$ and $(\mathrm{P}<0.001)$ from 100 and at 200 $\mathrm{mM} \mathrm{NaCl}$ respectively with increased salinity in the culture medium (Figure 1).

\section{Biochemical constituents}

The biochemical constituents (Proline content, Total free amino acid, Soluble carbohydrates and Total soluble carbohydrates) of white pepper significantly increased $(\mathrm{P}<0.001)$ with intake doses of $\mathrm{NaCl}$ from $50 \mathrm{mM} \mathrm{NaCl}$ compared to control (Figure 2).

\section{Non-enzymatic antioxidants}

The $\mathrm{NaCl}$ in the culture medium generally influenced the production of nonenzymatic antioxidants. Both the total phenol and flavonoid content significantly increased $(\mathrm{P}<0.001)$ with increased salinity compared to control (Figure 3). 
A. E. NOUCK et al. / Int. J. Biol. Chem. Sci. 15(4): 1457-1468, 2021

Table 1: Effects of salt stress on plant growth in white pepper after six weeks of treatment.

\begin{tabular}{|c|c|c|c|c|c|c|c|}
\hline \multirow[b]{2}{*}{ Cultivar } & \multirow{2}{*}{$\begin{array}{l}\text { Treatment } \\
\text { mM NaCl }\end{array}$} & \multicolumn{2}{|r|}{ Dry weight (g) } & \multirow[b]{2}{*}{$\mathrm{SH}(\mathrm{cm})$} & \multirow[b]{2}{*}{ NL } & \multirow[b]{2}{*}{ SD (mm) } & \multirow[b]{2}{*}{$\mathbf{L A}\left(\mathbf{c m}^{2}\right)$} \\
\hline & & RDW & SDW & & & & \\
\hline \multirow{4}{*}{$\begin{array}{l}\text { White } \\
\text { pepper }\end{array}$} & 0 & $1.21 \pm 0,03$ & $2.53 \pm 0.02$ & $31.03 \pm 2.96$ & $9.75 \pm 0.50$ & $1,54 \pm 0.08$ & $14.80 \pm 1.89$ \\
\hline & 50 & $1.07 \pm 0.04 \mathrm{a} n s$ & $2.16 \pm 0.05 \mathrm{a} \mathrm{ns}$ & $28.40 \pm 1.86 \mathrm{a} n s$ & $8.50 \pm 0.57 \mathrm{a} \mathrm{ns}$ & $1.43 \pm 0.07 \mathrm{a} n s$ & $12.24 \pm 1.22 \mathrm{a} \mathrm{ns}$ \\
\hline & 100 & $0.82 \pm 0.08 \mathrm{~b} * * *$ & $1.96 \pm 0.08 \mathrm{~b} * * *$ & $22.92 \pm 0.75 b^{* * *}$ & $7.25 \pm 0.95 b^{* *}$ & $1.09 \pm 0.03 b^{*}$ & $8.65 \pm 1.95 b^{* *}$ \\
\hline & 200 & $0.56 \pm 0.02 \mathrm{c} * * *$ & $1.16 \pm 0.04 c^{* * *}$ & $12.12 \pm 1.03 \mathrm{c} * * *$ & $4.75 \pm 0.50 \mathrm{c} * * *$ & $0.48 \pm 0.04 \mathrm{c}^{* * *}$ & $5.47 \pm 0.62 \mathrm{c}^{* * *}$ \\
\hline
\end{tabular}

Mean results of five replications $\pm \mathrm{SD}$. Based on the ANOVA method followed by all pairwise analysis using the Student-Newman-Keuls. ${ }^{\mathrm{ns}} \mathrm{P}>0.05 ; * \mathrm{P}<0.05 ; * * \mathrm{P}<0.01$ and $* * * \mathrm{P}<0.001$ as compared to $0 \mathrm{mM} \mathrm{NaCl}$. Letter showed the difference between the different concentrations $(\mathrm{P}<0.05)$.

Table 2: Effects of salt stress on mineral distribution $(\mu \mathrm{g} / \mathrm{g}$ MS) in white pepper after six weeks of treatment.

\begin{tabular}{|c|c|c|c|c|c|c|}
\hline \multirow{2}{*}{$\begin{array}{c}\text { Cultivar } \\
\text { White pepper } \\
\text { Organs }\end{array}$} & \multirow{2}{*}{$\begin{array}{l}\text { Treatment } \\
(\mathrm{mM} \mathbf{N a C l})\end{array}$} & \multicolumn{3}{|c|}{$\begin{array}{c}\text { Mineral distribution } \\
(\mu \mathrm{g}-1 \mathrm{MS})\end{array}$} & \multirow[b]{2}{*}{$\mathrm{Mg}^{2+}$} & \multirow[b]{2}{*}{$\mathbf{K}^{+} / \mathrm{Na}^{+}$} \\
\hline & & $\mathrm{Na}^{+}$ & $\mathbf{K}^{+}$ & $\mathrm{Ca}^{2+}$ & & \\
\hline \multirow{3}{*}{ Roots } & 0 & $34.18 \pm 2.73$ & $39.89 \pm 1.97$ & $46.94 \pm 3.49$ & $51.41 \pm 3.06$ & 1.16 \\
\hline & 50 & $47.29 \pm 2.91 \mathrm{a}^{* * *}$ & $35.54 \pm 2.37 \mathrm{ans}$ & $30.07 \pm 2.03 \mathrm{a}^{* * *}$ & $33.74 \pm 2.38 \mathrm{a}^{* * *}$ & 0.75 \\
\hline & 100 & $72.50 \pm 3.24 \mathrm{~b}^{* * *}$ & $33.33 \pm 3.40 \mathrm{ab}^{*}$ & $18.27 \pm 1.79 \mathrm{~b} * * *$ & $21.43 \pm 1.89 b^{* * *}$ & 0.45 \\
\hline \multirow{5}{*}{ Shoots } & 200 & $107.93 \pm 9.38 \mathrm{c} * * *$ & $31.89 \pm 3.80 b^{*}$ & $10.13 \pm 0.93 \mathrm{c} * * *$ & $17.41 \pm 2.53 \mathrm{c} * * *$ & 0.29 \\
\hline & 0 & $38.90 \pm 2.28$ & $77.14 \pm 5.35$ & $76.82 \pm 4.18$ & $80.30 \pm 5.68$ & 1.98 \\
\hline & 50 & $86.34 \pm 4.20 \mathrm{a}^{* * *}$ & $51.31 \pm 3.42 \mathrm{a}^{* * *}$ & $48.61 \pm 2.02 \mathrm{a} * * *$ & $56.57 \pm 3.96 \mathrm{a}^{* * *}$ & 0.59 \\
\hline & 100 & $119.67 \pm 8.86 b^{* * *}$ & $36.71 \pm 2.10 b^{* * *}$ & $30.61 \pm 0.75 b * * *$ & $35.23 \pm 4.98 \mathrm{~b} * * *$ & 0.30 \\
\hline & 200 & $222.48 \pm 27.56 \mathrm{c} * * *$ & $25.9 \pm 2.56 \mathrm{c} * * *$ & $21.68 \pm 1.07 \mathrm{c} * * *$ & $24.15 \pm 2.17 \mathrm{c} * * *$ & 0.11 \\
\hline
\end{tabular}

Mean results of five replications \pm SD. Based on the ANOVA method followed by all pairwise analysis using the Student-Newman-Keuls. ${ }^{\text {ns }} \mathrm{P}>0.05 ; * \mathrm{P}<0.05 ; * * \mathrm{P}<0.01$ and $* * * \mathrm{P}<0.001$ as compared to $0 \mathrm{mM} \mathrm{NaCl}$. Letter showed the difference between the different concentrations $(\mathrm{P}<0.05)$. 


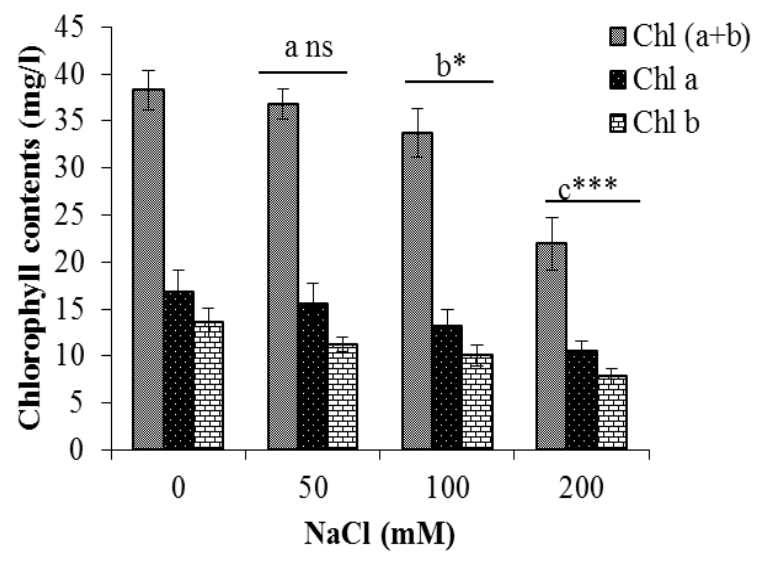

Figure 1: Effects of $\mathrm{NaCl}$ concentrations on the chlorophyll content $\mathrm{a}, \mathrm{b},(\mathrm{a}+\mathrm{b})$ of white pepper. Mean results of five replications \pm SD. Based on the ANOVA method followed by all pairwise analysis using the studentNewman-keuls. ${ }^{\text {ns }} \mathrm{P}>0.05 ;{ }^{*} \mathrm{P}<0.05$ and $* * * \mathrm{P}<0.001$ as compared to $0 \mathrm{mM} \mathrm{NaCl}$. Letter showed the difference between the different concentrations $(\mathrm{P}<0.05)$.
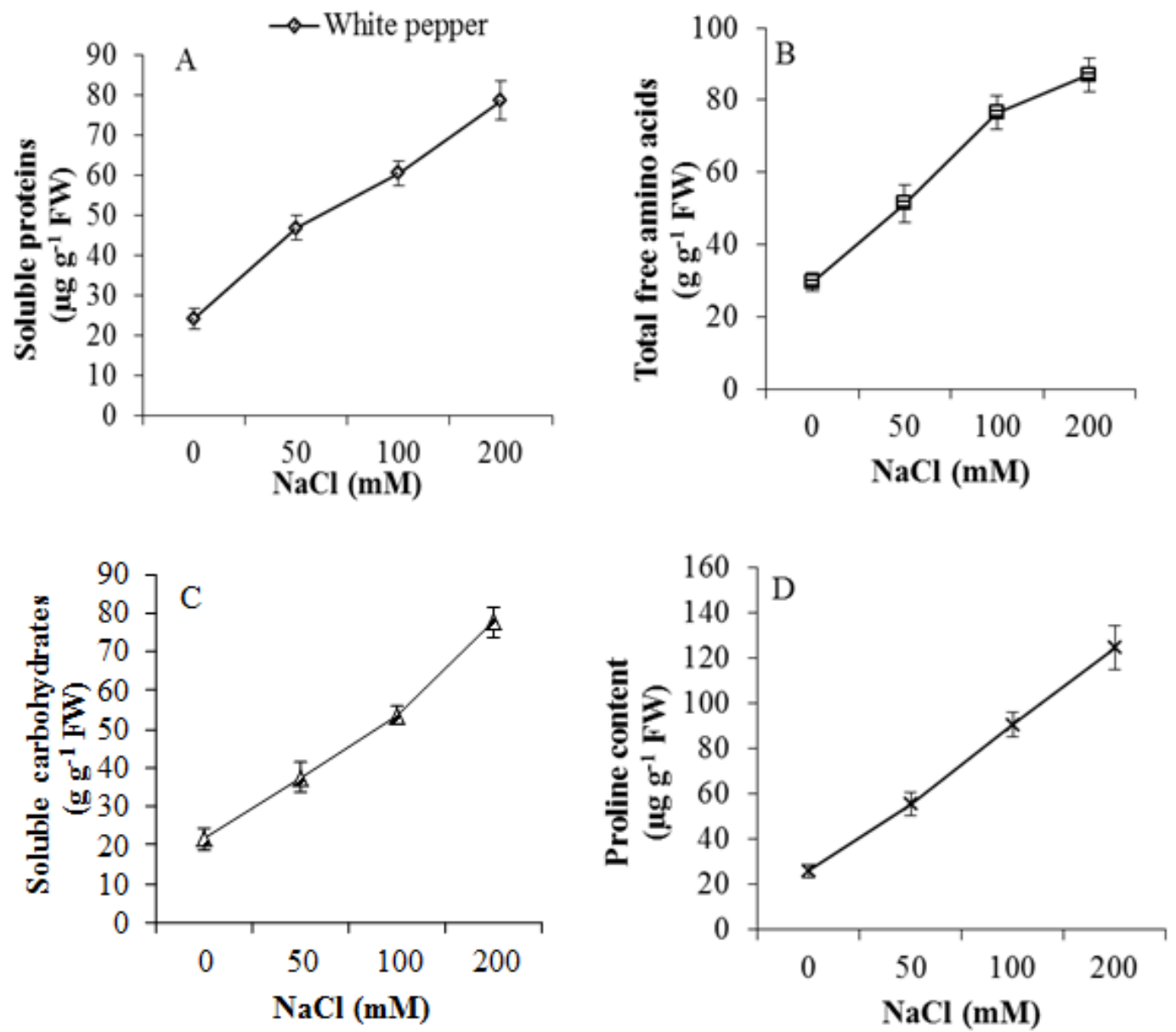

Figure 2: Effects of $\mathrm{NaCl}$ on accumulation of biochemical constituents in white pepper. A: Soluble proteins; B: Total free amino acids; C: Soluble carbohydrates and D: Proline content. Bars are means $(n=5) \pm S D$. 

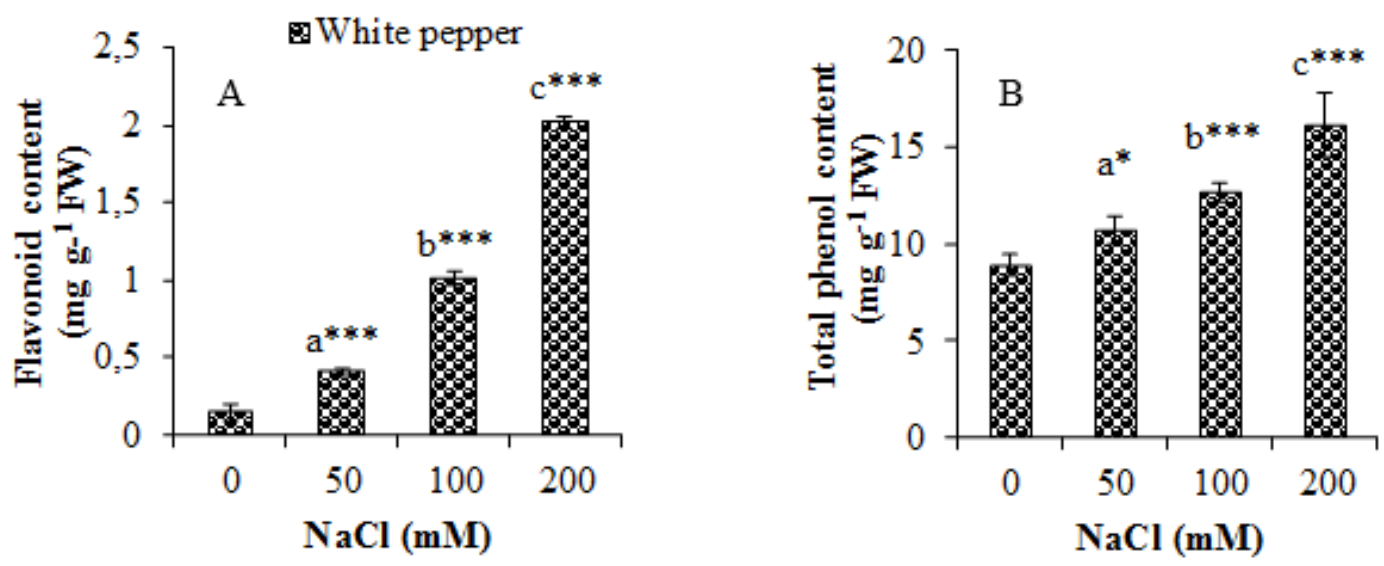

Figure 3: Effects of $\mathrm{NaCl}$ on accumulation of non-enzymatic antioxidants in white pepper.

A: Flavonoid content and B: Total phenolic content. Mean results of five replications \pm SD. Based on the ANOVA method followed by all pairwise analysis using the Student-Newman-Keuls. $* \mathrm{P}<0.05$ and $* * * \mathrm{P}<0.001$ as compared to $0 \mathrm{mM}$ $\mathrm{NaCl}$. Letter showed the difference between the different concentrations $(\mathrm{P}<0.05)$.

\section{DISCUSSION}

The stem height decrease from 100 $\mathrm{mM} \mathrm{NaCl}$ due to the detrimental effects of $\mathrm{NaCl}$ on plants which are consequences of biochemical changes that inhibit plant growth and development, negatively affecting photosynthetic activities, proteins synthesis, nucleic acids metabolism and water availability (Taffouo et al., 2010). Depletion in plant growth (RDW and SDW) according to Menguekam et al. (2014) is due to limited hydrolysis of food reserved from storage tissue to the developing embryo and a reduction of water uptake. The decrease of RDW and SDW has been mentioned by previous workers (Navarro et al. (2014); Hand et al. (2017) and Ndouma et al. (2020) respectively on Citrus reshni (L.) and Citrus macrophylla (L.), Capsicum annuum (L.) and Dioscorea rotundata (L.) respectively. Hand et al. (2017) and Ndouma et al. (2020) showed that the number of leaves decreased with the intake doses of $\mathrm{NaCl}$ due to the accumulation of $\mathrm{Na}^{+}$in the cytoplasm of leaves. At the same time their fluid vacuoles cannot store salt and consequently shed their leaves and died due to increase the salt concentrations in the cell. Ndouma et al. (2020) adhere that, the decrease in leaf area with the intake doses of $\mathrm{NaCl}$ in the culture medium affects several physiological responses including ion balance, stomatal behavior, mineral nutrition and photosynthetic efficiency. Dadkhah (2011) on Beta vulgaris $\mathrm{L}$ showed that the decrease of noose diameter with salt stress is a consequence of physiological responses like the modification of ionic equilibrium, mineral nutrition disruption which inhibited the accumulation of mineral ions in the tissues.

The results showed that $\mathrm{Na}^{+}$increased with increased salinity in both shoots and roots while others minerals $\left(\mathrm{K}^{+}, \mathrm{Ca}^{2+}\right.$ and $\mathrm{Mg}^{2+}$ ) decreased. According to Assaha et al. (2017), $\mathrm{Na}^{+}$in plants increased with increased salinity due to imbalance in the $\mathrm{K}^{+} / \mathrm{Na}^{+}$ transporters. The ratio is distorted by the high salt concentration in the soil, which enhanced the uptake of $\mathrm{Na}^{+}$. These results correspond to those of Mohamdi et al. (2011), Hand et al. (2017) and Ndouma et al. (2020). They showed that, the competition of $\mathrm{Na}^{+}$and $\mathrm{K}^{+}$ for aerial plants resulted in greater accumulation of $\mathrm{Na}^{+}$in the shoots than in the roots, additional it can be caused by the loss of osmotic potential of root medium and the lack of nutritional ions. They also indicated that the uptake of $\mathrm{Na}^{+}$inhibits the uptake and transportation of others mineral $\left(\mathrm{K}^{+}, \mathrm{Ca}^{2+}\right.$ and $\mathrm{Mg}^{2+}$ ) elements to the leaves. The decrease of 
$\mathrm{Ca}^{2+}$ in the culture medium, according to Rahneshan et al. (2018), $\mathrm{Ca}^{2+}$ ameliorates salt stress through osmotic adjustments by enhancing ion uptake and increasing the selectivity $\mathrm{K}^{+/} \mathrm{Na}^{+}$. The decreased of $\mathrm{Mg}^{2+}$ with increased salinity as reported by Theerawitaya et al. (2015) was attributed to the fact that salinity affects plant physiology through changes of water and ions status in the cells because of ionic imbalance due to excessive accumulation of $\mathrm{Na}$ and $\mathrm{Cl}$, and the $\mathrm{Na}^{+} / \mathrm{K}^{+}$antagonism which favored the uptake of $\mathrm{Na}^{+}$over other minerals like $\mathrm{Mg}^{2+}, \mathrm{K}^{+}$, and $\mathrm{Ca}^{2+}$ (Hand et al., 2017).

The inverse relation between salinity and chlorophyll contents $\mathrm{Chl} \mathrm{a,} \mathrm{b}$ and $(\mathrm{a}+\mathrm{b})$ has been reported in a number of studies. Heidari (2012) reported that chlorophyll content reduced with increased salinity due to the accumulation of salts in older leaves which caused them eventually die and drop off, and also photoinhibitory damage caused by the activation of chlorophyll degradation by chlorophyllase.

The plant supplied with intake doses of $\mathrm{NaCl}$ in the culture medium showed significant increase and accumulation of PRO, $\mathrm{CH}, \mathrm{FAA}$ and PR content. These results are in consonance with the findings of Kosova et al. (2013) and hand et al. (2017). They reported that soluble proteins increased due to regulatory adjustments to stress resulting in its active synthesis. This is because soluble proteins enhance plant salt tolerance. Its production is considered as an adaptive mechanism of plants to salinity. The findings of Nouck et al. (2016) and Ndouma et al. (2020) indicated that the increases of free amino-acids with increased salinity was due to the reduction of osmotic potential to maintain the turgid potential. According to Nemati et al. (2011), and osmotic stress caused by physiological drought which was responsible for decreased osmotic potential leading to the active synthesis and accumulation of total soluble carbohydrates which enhance plant salt tolerance. Proline like other biochemical constituents increased with intake doses of
$\mathrm{NaCl}$. These results are consistent with those of Khalil et al. (2016). They reported that large quantities of proline are produced under saline conditions depending on the salt tolerance of the plant concerned. This is because proline functions in osmotic adjustment, stabilizing and protecting membrane integrity in saline conditions.

The results of that non-enzymatic antioxidants (total phenolic (TP) and flavonoid (FLA)) accumulated under stress condition corroborates those of Menguekam et al. (2014), Taïbi et al. (2016) and Ndouma et al. (2020). These authors maintain that the accumulation of TP and FLA are physiological responses to plant stress. Their accumulation is a cellular adaptive mechanism for scavenging oxygen free radicals, while maintaining chlorophyll levels and cell turgor to protect photosynthetic activities.

\section{Conclusion}

The results of the present study revealed that white pepper (Piper nigrum L.) was affected with the increased $\mathrm{NaCl}$ in the culture medium during six weeks. The mineral distribution $(\mathrm{K}, \mathrm{Ca}, \mathrm{Mg}$ and $\mathrm{K} / \mathrm{Na}$ ) in the roots and shoots were decreased with increasing intake doses of $\mathrm{NaCl}$ while $\mathrm{Na}$ increased from $50 \mathrm{mM} \mathrm{NaCl}$, and the highest concentrations of $\mathrm{Na}$ were observed in the shoot than roots. The roots and shoots dry weight, stem height, noose diameter, leaf area, number of leaves, chlorophyll a, b and total decreased from 100 $\mathrm{mM} \mathrm{NaCl}$. The total soluble carbohydrates, total free amino acids, soluble proteins, proline, total phenolic and flavonoids compounds increased from $50 \mathrm{mM} \mathrm{NaCl}$. The main strategy of salt-tolerance in white pepper seems to increase osmotic adjustment through the strongly accumulation of SP, CH, PRO, FAA, TP and FLA in leaves. Thus, their higher accumulation could be considered as potential biochemical indicators of early identification and osmotic adjustment ability for salt-tolerant plants in salt stress conditions. The white pepper cultivar could be cultivated in the soil with moderate salinity. 


\section{COMPETING INTERESTS}

The authors declare that there is no conflict of interest and the manuscript has not been submitted elsewhere.

\section{AUTHORS' CONTRIBUTIONS}

The seven authors conceived the idea of the study, designed the study, read and approved the final draft. Author NAE wrote the protocol, conducted the experiment, wrote the first draft and came out with the final draft, Authors HMJ, NEN and ESS took part in the lab analyses, preparing and editing the manuscript. Authors NMC and EWC corrected the first draft, researched the literature and did the statistical analysis and author TVD corrected the first and the final draft, made some technical inputs and supervised the editing of the manuscript.

\section{ACKNOWLEDGMENTS}

The author thanks Dr Fokom and Dr Adamu of the biotechnology center of Nkolbisson for their excellent technical assistance.

\section{REFERENCES}

Arnon DI. 1949 Copper enzymes in isolated chloroplasts. Polyphenylodase in Beta vulgaris. Plant Physiol., 24 (1): 1-15. DOI: 10.1104/pp.24.1.1.

Assaha DVM, Ueda A, Saneoka H, Al-Yahyai $\mathrm{R}$, Yaish M, 2017. The role of $\mathrm{Na}^{+}$and $\mathrm{K}^{+}$transporters in salt stress adaptation in glycophytes. Front. Physiol., 8: 509. DOI: doi.org/10.3389/fphys.2017.00509.

Bates L, Waldren RP, Teare ID. 1973. Rapid determination of free proline for waterstress studies. Plant and Soil., 39 (2): 205-207.

DOI: doi.org/10.1007/BF00018060

Bradford MM. 1976. A rapid and sensitive method for quantitation of microgram of protein utilizing the principle of proteindye binding. Anal Biochem., 72(1-2): 248-254. DOI: doi.org/10.1016/00032697 (76)90527-3.

Chang CC, Yang MH, Wen HM, Chern JC. 2002. Estimation of total flavonoid content in propolis by two complementary colorimetric methods. $J$. Food. Drug. Anal., 10(3): 178-182. DOI: $10.38212 / 2224-6614.2748$.

Cheynier V, Comte G, Davies K.M, Lattanzio V, Martens S. 2013. Plant phenolics: Recent advances on their biosynthesis, genetics, and ecophysiology. Plant Physiol Biochem., 72: 1-20. DOI: doi.org/10.1016/j.plaphy.

Dadkhah A. 2011. Effect of salinity on growth and leaf photosynthesis of two sugar beet (Beta vulgaris L.) cultivars. J. Agr. Sci. Tech., 13(7): 1001-1013.

Diallo B, Samba SAN, Sane D, Diop T. 2013. Effet du chlorure de sodium sur la germination de graines de Ricinus communis L. Int. J. Biol. Chem. Sci., 7(4): $\quad$ 1534-1544. DOI: $10.4314 /$ ijbcs.v7i4.10.

Di Ferdinando M, Brunetti C, Fini A, Tattini M. 2012. Flavonoids as Antioxidants in Plants under Abiotic Stresses. In Abiotic Stress Responses in Plants: Metabolism, Productivity and Sustainability, Ahmad P, Prasad MNV (Eds). Springer: New York; 159-179.

Dubois M, Gilles KA, Hamil JK, Rebers PA, Smith F. 1956. Colorimetric method for determination of sugars and related substances. Anal Chemistry, 28(3): 350356.

DOI : doi.org/10.1021/ac60111a017.

Hand MJ, Taffouo VD, Nouck AE, Nyemene KPJ, Tonfack LB, Meguekam TL, Youmbi E. 2017. Effects of Salt Stress on Plant Growth, Nutrient Partitioning, Chlorophyll Content, Leaf Relative Water Content, Accumulation of Osmolytes and Antioxidant Compounds in Pepper (Capsicum annuum L.) Cultivars. Not Bot Horti Agrobo., 45(2): 481-490. DOI:10.15835/nbha45210928.

Heidari M. 2012. Effects of salinity stress on growth, chlorophyll content and osmotic components of two basil (Ocimum basilicum L.) genotypes. Afr. J. Biotechnol., 11(12): 379-384. DOI: 10.5897/AJB11.2572. 
Hoagland DR, Arnon DI. 1950. The waterculture method for growing plants without soil. University of California, College of Agriculture, Berkley; 1-34.

Khalil C, Abdelmajid H, Mohammed HE, Houssein BB. 2016. Growth and proline content in $\mathrm{NaCl}$ stressed plants of annual medic species. Int. J. Adv. Res. Biol. Sci., 3(9): 82-90. DOI: 10.22192/ijarbs.

Kinsou E, Amoussa AM, Mensah ACG, Kpinkoun JK, Komlan FA, Ahissou H, Lagnika L, Gandonou CB. 2021. Effet de la salinité sur la floraison, la fructification et la qualité nutritionnelle des fruits du cultivar local Akikon de tomate (Lycopersicon esculentum Mill.) du Bénin. Int. J. Biol. Chem. Sci., 15(2): 737-749.

DOI:

https://dx.doi.org/10.4314/ijbcs.v15i2.27

Kosová K, Prášil IT, Vítámvás P. 2013. Protein Contribution to Plant Salinity Response and Tolerance Acquisition. Int. J. Mol. Sci., 14: 6757-6789. DOI: 10.3390/ijms 14046757.

Kpinkoun KJ, Amoussa AM, Mensah ACG, Assogba-Komlan F, Lagnika L, Gandonou CB. 2019. Effect of salt stress on flowering, fructification and fruit nutrients concentration in local cultivar of chili pepper (Capsicum frutescens L.). Int. J. Plant Physiol. Biochem., 11(1): 17.

DOI: https://doi.org/10.4314/jab.v133i1.8.

Marigo G. 1973. On a fractionation method and estimation of the phenolic compounds in plant. Analysis., 2(2): 106110.

Maydell HJ. 1986. Trees and Shrubs of the Sahel; their Characteristics and Uses. D-6101 523pp.

Meghwal M, Ghoswani TK. 2012. Chemical composition, nutritional, medicinal and functional properties of black pepper: A Review. Open Access Scientific Reports, 1: 172 . DOI: 10.4172/scientificreports. 172 .

Meguekam TL, Taffouo VD, Grigore MN, Zamfirache MM, Youmbi E, Amougou A. 2014. Differential responses of growth, chlorophyll content, lipid perodxidation and accumulation of compatible solutes to salt stress in peanut (Arachis hypogaea L.) cultivars. Afr. J. Biotechnol., 13(50): 4577-4587. DOI: $10.5897 / A J B 2014.14248$.

Mohamdi OM, Bouya D, Salem MOA. 2011. Etude de l'effet du stress salin $(\mathrm{NaCl})$ chez deux variétés de tomate (Campbell 33 et Mongal). Int. J. Biol. Chem. Sci., 5(3): $\quad 890-900 . \quad$ DOI: 10.4314/ijbcs.v5i3.72171.

Munns R, Tester M. 2008. Mechanisms of salinity tolerance. Аnnu. Rev. Plant Biol., 59(1): 651-681. DOI: 10.1146/annurev.arplant.59.032607.0929 11.

Navarro JM, Tornero OP, Morte A. 2014. Alleviation of salt stress in citrus seedlings inoculated with arbuscular mycorrhizal fungi depends on the rootstock salt tolerance. J. Plant. Physiol., 171 (1): 76-85. DOI: 10.1016/j.jplph.2013.06.006.

Ndouma MC, Nouck AE, Titah MA, Ndjouondo GP, Ekwel SS, Fotso, Taffouo VD. 2020. Growth parameters, mineral distribution, chlorophyll content, biochemical constituents and nonenzymatic antioxidant compounds of white yam (Dioscorea rotundata (L) var. gana) grown under salinity stress. GSC Biological and Pharmaceutical Sciences, 12(03): $\quad 139-149 . \quad$ DOI: 10.30574/gscbps.2020.12.3.0286.

Nemati I, Moradi F, Gholizadeh S, Esmaeili MA, Bihamta MR. 2011. The effect of salinity stress on ions and soluble sugars distribution in leaves, leaf sheaths and roots of rice (Oryza sativa L.) seedlings. Plant Soil Environ., 57: 26-33. DOI: doi.org/10.17221/71/201 0-PSE.

Nouck AE, Taffouo VD, Tsoata E, Dibong SD, Nguemezi ST, Gouado I, Youmbi E. 2016. Growth, Biochemical Constituents, Micronutrient Uptake and Yield Response of Six Tomato (Lycopersicum esculentum L.). J. Agro., 15 (2): 58-67. DOI: 10.3923/ ja.2016. 
Nwoboshi LC. 1982. Tropical Silviculture, Principles and Techniques. Ibadan University Press, Ibandan, Nigeria;1333.

Pauwels JM, Van Ranst E, Verloo M, Mvondo ZA. 1992. Analysis Methods of Major Plants Elements. Pedology Laboratory Manual: Methods of plants and Soil Analysis. Stock Management Equipment of Worms and Chemical Equipment. AGCD, Agriculture Publications : Brussels; 1-28.

Rahneshan Z, Nasibi F, Moghadam AA. 2018. Effects of salinity stress on some growth, physiological, biochemical parameters and nutrients in two pistachio (Pistacia vera L.) root stocks. J. Plant-Environ Inter., 13(1): 73-82. DOI: doi.org/10.1080/17429145.2018.142435 5.

Scot NS, Eger KT. 2011. (revised). Farm and Forestry Production and Marketing Profile for Black Pepper (Piper nigrum). In Specialty Crops for Pacific Island Agroforestry, Elevitch CR (ed.).
Permanent Agriculture Resources (PAR): Holualoa, Hawai' $\mathrm{i}$; 1-14.

Taïbi K, Taïbi F, Abderrahim LA, Ennajah A, Belkhodja M, Mulet JM. 2016. Effect of salt stress on growth, chlorophyll content, lipid peroxidation and antioxidant defense systems in Phaseolus vulgaris L. S. Afr. J. Bot., 105: 306-312. DOI: doi.org/10.1016/j.sajb.2016.03.011.

Taillièz, Ballo Koffi. 1992. Une méthode de mesure de la surface foliaire du palmier á huile. Oléagineux, 47(8-9): 537-553.

Therawitaya C, Tisarum R, Samphumphuang T, Singh HP, Cha-Um S, Kirmanee C, Takabe T. 2015. Physio-biochemical and morphological characters of halophytes legumes shrub, Acacia ampliceps seedlings in response to salt stress under green house. Front. Plant Sci., 6:630. DOI: doi.org/10.3389/fpls.2015.00630.

Yemm EW, Cocking EC.1955. The determination of amino acids with ninhydrin. The Analyst, 80: 209-213. DOI: $10.1039 / \mathrm{an} 9558000209$. 